\title{
Multi-Criteria Decision Making (MCDM ) Approach for Selecting Solar Plants Site and Technology: A Review
}

\author{
Roghayeh Ghasempoura, Mohammad Alhuyi Nazaria, Morteza Ebrahimia , \\ Mohammad Hossein Ahmadi ${ }^{b^{*}}$, H. Hadiyanto ${ }^{\mathrm{c}}$
}

\author{
${ }^{a}$ Faculty of New Sciences and Technologies, Tehran University, A.C., Tehran, Iran \\ ${ }^{b}$ Faculty of Mechanical Engineering, Shahrood University of Technology, Shahrood, Iran \\ ‘Department of Chemical Engineering, University of Diponegoro Jl. Prof. Sudharto, Tembalang, Semarang, 50239, Indonesia
}

\begin{abstract}
Renewable energies have many advantages and their importance is rising owing to gravely mounting concerns for environmental issues and lack of fossil fuels in the future. Solar energy, well acknowledged as an inexhaustible source of energy, is developing dramatically for different purposes such as desalination and electricity generation. Appropriate solar power plant is very important factor for power generation due to its cost and other constraints. The applied technology is as important as the solar power plants location. In this paper, a wide variety multi criteria decision making (MCDM) methods, investigated by various researchers, are presented to obtain effective criteria in selecting solar plants sites and solar plants technologies. There is not any comprehensive research providing all required criteria for decision making for site and technology selection. Based on the reviewed researches, weight of each criterion depends on many factors such as region, economy, accessibility, power network, maintenance costs, operating costs, etc. The important criteria for site selection are represented and investigated thoroughly in this review paper.
\end{abstract}

Keywords: Solar Energy, PV, MCDM, Renewable Energy

(C) 2019. CBIORE-IJRED. All rights reserved

Article History: Received June 17th 2017; Received in revised form March $7^{\text {th }}$ 2018; Accepted June 16 th 2018; Available online

How to Cite This Article: Ghasempour, R., Nazari, M.A., Ebrahimi, M., Ahmadi, M.H. and Hadiyanto, H. (2019) Multi-Criteria Decision Making (MCDM ) Approach for Selecting Solar Plants Site and Technology: A Review. Int Journal of Renewable Energy Development, 8(1), 1525.

https://doi.org/10.14710/ijred.8.1.15-25

\section{Introduction}

Energy is necessary for different human activities such as heating (Arab et al 2012), transportation and some other purposes like desalination systems (Jahangiri et al. 2014; Olimat 2017; Tarwidi et al 2016). Over the past century, fossil fuels have provided most of human energy demand; however, due to growing environmental concerns and predicted lack of fossil fuels in the near future, there are many attempts to find appropriate alternative resources for energy which is environmentally benign and renewable (Toghi et al. 2015, Dellosa 2016). In addition, reducing the emission of greenhouse gases is an urgent necessity and it is achievable by using renewable energies (Narei et al 2016).

Demand for electricity, one of the most important infrastructures of every country, is growing continuously hence development in industrial and economic activities as well as population growth. Due to these facts, electricity generation plays a main role in energy policies and the mismanagement of electricity generation has undesirable effects on the environment. In addition, selecting the best method for electricity generation affects human life standards. Many parameters influence the type of electricity generation plants such as environmental and economic ones (Hoque, et al. 2016; Naick et al 2017). Multi-Criteria Decision Making (MCDM) techniques which are used to select the best spot for energy generation plants based on the priorities and available data are gaining considerable popularity (Kumar and Singal 2015). MCDM techniques are being applied for problems with incompatible and various objectives (Pohekar and Ramachandran 2004).

Chatzimouratidis et al (2009) who investigated different power plants, their results showed that, based on the subjective criteria weighting, the priority depends on sustainability driving renewable energy power plants, while nuclear and fossil fuel power plants rankings had the least priority among investigated options. Environmental concerns are growing in the world and it is necessary to find methods in order to find environmentally benign power plants. Based on this fact, conventional electricity generation methods will be replaced with renewable energies. Selection of renewable

\footnotetext{
*Corresponding author: mohammadhosein.ahmadi@gmail.com
} 
Citation: Ghasempour, R., Nazari, M.A., Ebrahimi, M., Ahmadi, M.H. and Hadiyanto, H. (2019) Multi-Criteria Decision Making (MCDM) Approach for Selecting Solar Plants Site and Technology: A Review. Int. Journal of Renewable Energy Development, 8(1), 15-25, doi.org/10/14710/ijred.8.1.15-25

$\mathrm{P}$ a g e 16

alternatives is a multi-criteria problem owing to the existence of various inconsistent criteria (Kahraman et al 2009). Thus, it is essential to assess possible alternatives by considering their advantages and disadvantages (Kahraman et al 2009; Kabak and Dağdeviren 2014; Nigim et al 2004; Ahmad and Mat Tahar 2014; Şengül et al. 2015; Amer and Daim 2011).

Among the renewable energy resources, solar energy is arousing considerable interest nowadays because of its availability and economic aspects (Askari et al 2015). Nevertheless, Solar plants have imposed some strict, for example solar thermal power plants are ideally appropriate for locations with at least $2000 \mathrm{~kW} \mathrm{~h} / \mathrm{m} 2 /$ year solar radiation, low humidity and dust and other agents which prevents absorption of solar irradiation (Cavallaro, 2010). Another factor which is very important in solar energy is plant location and sunlight hours. Installation of solar power plants in regions enjoying district advantages in terms of appropriate sunlight hours and radiation is a strategic necessity.

In the selection suitable location for solar farms, various parameters including economic aspects, accessibility of site, and environmental issues, and energy policy restrictions must be considered (Vafaeipour et al. 2014). To achieve the most favorable financial output and efficiency, it is crucial to identify and select the best location for solar power plants. The mechanisms of utilizing solar energy technologies depends on many influencing factors and constraints (Chatzimouratidis and Pilavachi, 2008). The decision to choose certain mechanisms (policy instruments) is made according to MCDM which facilitates the transformation of subjective value judgments into prudent decisions (Chatzimouratidis and Pilavachi 2008). MCDM techniques have been applied for evaluation of suitable locations for the installation of solar power plants (Sánchez-Lozano et al 2015). In addition, MCDM techniques have been used for other aspects of solar energy such as evaluation policies in upstream of solar energy industry, enablers in solar power development, and exploring tapping potential (Shiue and Lin 2012; Luthra et al. 2016; Singhet al 2016).

For instance, in a research conducted by Beltrán et al (2014) to evaluate solar thermal plant. MCDM approach was applied to decide whether to have investment in solar thermal power plant to evaluate the priorities of the project. The researches have not been just limited to solar thermal power plants. Some projects have been done on photovoltaic industry for electricity generation based on MCDM. For instance, Tang et al (2014) conducted a study in order to investigate the potential space for each technology based on the MCDM approach. Zeyuan (2013) also investigated selection of solar cell type based on TOPSIS method. And the Results showed that the monocrystalline silicon solar cells were more beneficial compared with polycrystalline silicon and thin-film solar cells. In addition to selecting the types of cells, MCDM approach has been used in evaluation of material used in cell as well. For example, Gupta considered material properties such as band gap, absorption properties, thermodynamic compatibility, diffusion length, and recombination velocity as the main criteria for selecting the best material for thin-film solar cells (Gupta 2011).

Obtaining effective criteria in decision making process is the most crucial step. All advantages and disadvantages should be considered in making decision for solar power plants. In this paper, some of the most valuable studies in this field are reviewed and presented to achieve all required criteria. This paper consists of two main subsections; firstly, the criteria in site selection are represented and investigated, and secondly, possible technologies and effective factors for choosing the technology are comprehensively discussed. Based on the reviewed studies, it is concluded that there are various criteria for both site and technology selections and the importance of each criterion is closely dependent on regional, economical, energy policy and other probable parameters of the case study as well as energy policy.

\section{MCDM Approach in selecting solar power plant location}

In Site selection for renewable energies has high importance (Noorollahi et al 2015). Hence, MCDM approach has been widely used in solar technology site selection (Sánchez-Lozano et al 2013).

Table 1.

Triangular fuzzy number of linguistic variable used in the study (Kengpol et al 2013)

\begin{tabular}{lll}
\hline $\begin{array}{l}\text { Linguistic } \\
\text { variable }\end{array}$ & $\begin{array}{l}\text { Triangular fuzzy } \\
\text { number }\end{array}$ & $\begin{array}{l}\text { Reciprocal } \\
\text { fuzzy numbers }\end{array}$ \\
\hline $\begin{array}{l}\text { Extremely } \\
\text { strong }\end{array}$ & $(9,9,9)$ & $(1 / 9,1 / 9,1 / 9)$ \\
Very strong & $(6,7,8)$ & $(1 / 8,1 / 7,1 / 6)$ \\
$\begin{array}{l}\text { Strong } \\
\text { Moderately }\end{array}$ & $(4,5,6)$ & $(1 / 6,1 / 5,1 / 4)$ \\
strong & $(2,3,4)$ & $(1 / 4,1 / 3,1 / 2)$ \\
Equally strong & $(1,1,1)$ & $(1,1,1)$ \\
Intermediate & $(7,8,9),(5,6,7),(3,4,5)$, & $(1 / 9,1 / 8,1 / 7),(1 / 7,1$ \\
& $(1,2,3)$ & $/ 6,1 / 5),(1 / 5,1 / 4,1)$, \\
& & $(1 / 3,1 / 2,1 / 1)$ \\
\hline
\end{tabular}

Many parameters affecting decision making and some of them is exhaustively discussed here by presenting a number of researches conducted on selecting the solar power plants. Kengpol et al (2013) investigated the solar power plant locations by applying Fuzzy Analytic Hierarchy Process (FAHP) and Technique for Order of Preference by Similarity to Ideal Solution (TOPSIS) methods. They studied geographical distribution of sum of direct normal irradiation in their case study, Thailand. Then in their project, TOPSIS was combined with FAHP to prevent any mistake which may result from the possibility that experts are apt to form biased judgments on comparing preferences of a criterion over other criteria. Five main criteria were selected to evaluate site locations. Figure 1 shows the hierarchy of site selection problem involved in the study. Triangular fuzzy numbers of linguistic variables used in their study were defined as shown in Table 1. 


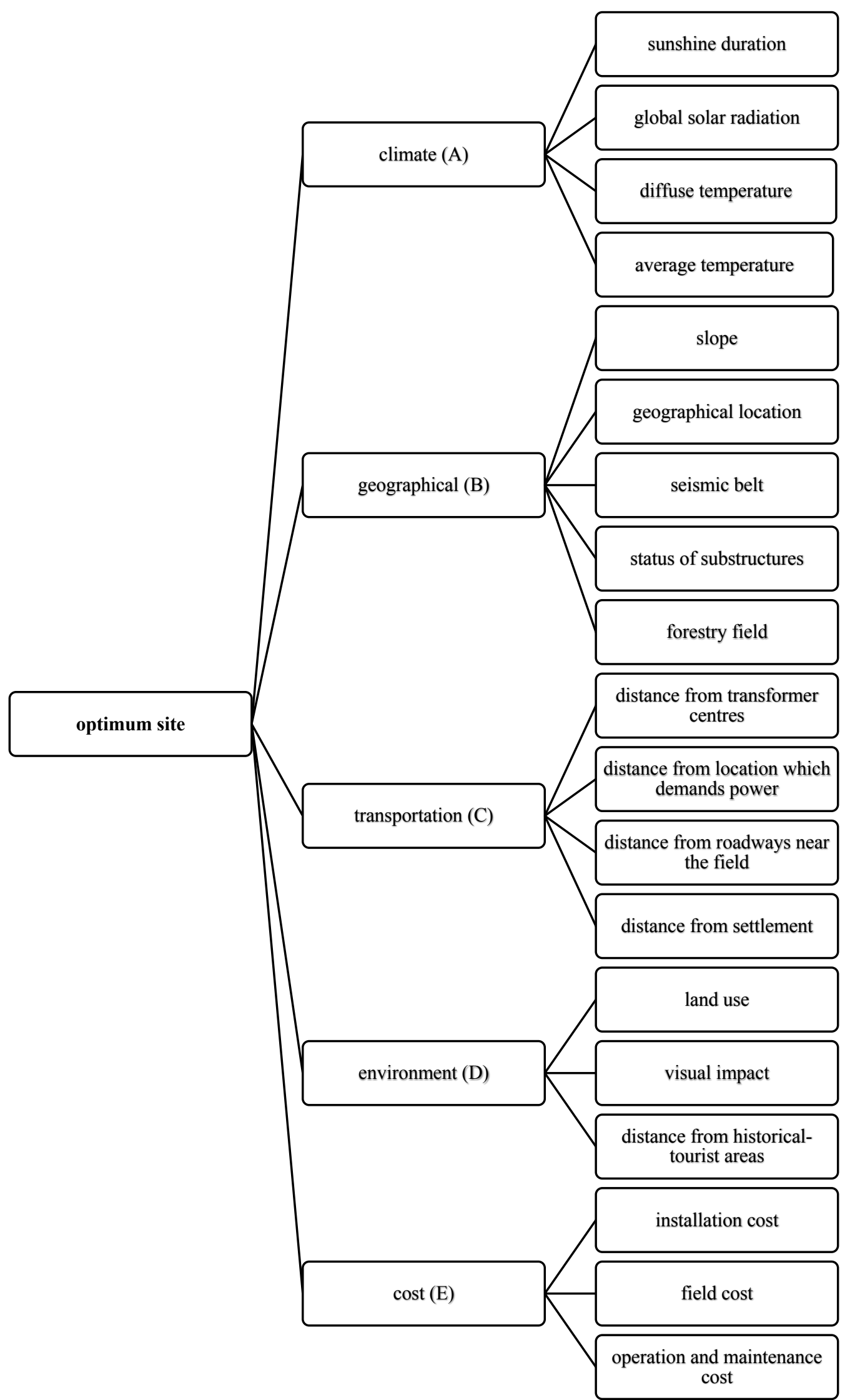

Fig. 1 The hierarchy of site selection problem (Kengpol et al 2013)

The obtained weights of sub criteria in this work are as shown in Table 2 : 
Citation: Ghasempour, R., Nazari, M.A., Ebrahimi, M., Ahmadi, M.H. and Hadiyanto, H. (2019) Multi-Criteria Decision Making (MCDM) Approach for Selecting Solar Plants Site and Technology: A Review. Int. Journal of Renewable Energy Development, 8(1), 15-25, doi.org/10/14710/ijred.8.1.15-25

$\mathrm{P}$ a g e $\mid 18$

Table 2.

The weight summarized of sub criteria (Kengpol et al 2013)

\begin{tabular}{lc}
\hline Sub criteria & Weight \\
\hline Sunshine duration & 0.231 \\
Global solar radiation & 0.000 \\
Diffuse radiation & 0.769 \\
Average temperature & 0.000 \\
Slope & 0.040 \\
Geographical location & 0.000 \\
Seismic belt & 0.437 \\
Status of substructure & 0.214 \\
Forestry field & 0.309 \\
Distance from transformer centres & 0.341 \\
Distance from the location which & 0.000 \\
demand power & \\
Distance from roadways near the & 0.659 \\
field & \\
Distance from the settlement & 0.000 \\
Land use & 0.573 \\
Visual impact & 0.427 \\
Distance from historical-tourist & 0.000 \\
area & \\
Installation cost & 0.717 \\
Field cost & 0.283 \\
Operation and maintenance cost & 0.000 \\
\hline
\end{tabular}

Selection of site location was carried out based on the mentioned sub criteria and the priority weights of alternative option with respect to main goal.

Another study was done by Asakereh et al (2014) for selecting solar energy sites in Shodirwan region in Iran applied Geographic Information System (GIS)-based, a tool to find appropriate power plant location (Noorollahi et al 2015) fuzzy AHP model. In this study, they used slope, aspect, road adjacency and grid accessibility raster map in fuzzy AHP model. In their research, to any cell slope smaller than $3 \%$, the value of 1 was assigned, and for slope in the range of $3 \%$ to $10 \%$ values from 1 to 0 were given as defined below (Asakereh, et al. 2014):

$S_{\text {value }}=\left\{\begin{array}{c}1 \\ \frac{x-10}{-7} \\ 0\end{array}\right.$

$$
\begin{gathered}
x \leq 3 \\
3 \leq x \leq 10 \\
\text { otherwise }
\end{gathered}
$$

Where $\mathrm{x}$ showed the slope of cell (\%) and $\mathrm{S}$ was any sell in slope map of case study.

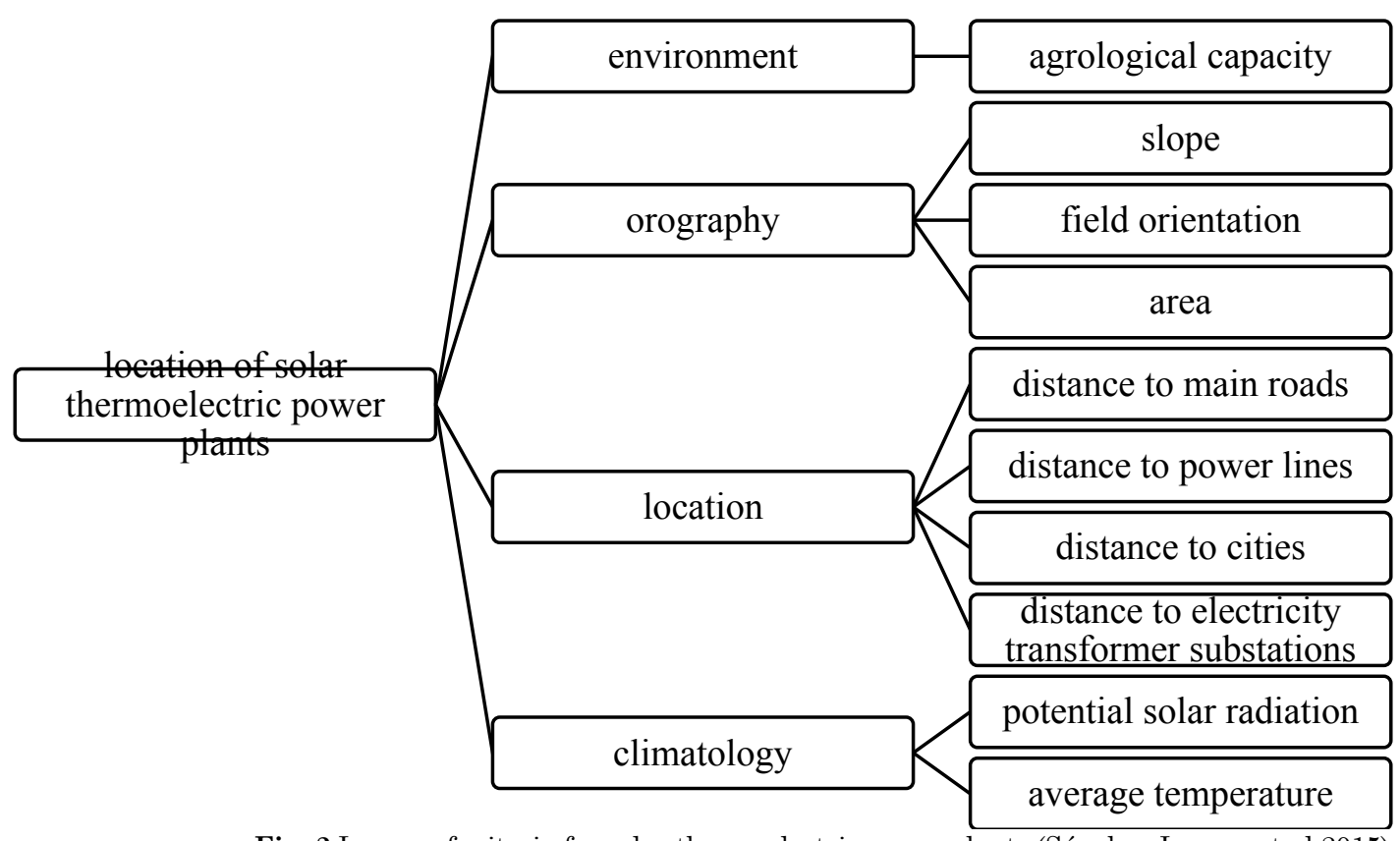

Fig. 2 Layers of criteria for solar thermoelectric power plants (Sánchez-Lozano et al 2015)

South-facing locations are more appropriate sites for solar farms based on southern exposure which leads to higher efficiency. The following values were belonged to aspect raster map as shown below (Asakereh, et al. 2014):

$A_{\text {value }}=$

$$
\left\{\begin{array}{cc}
\frac{x_{\text {degrege }}-112.5}{33.5} & 112.5 \leq x_{\text {degree }} \leq 146 \\
1 & 146 \leq x_{\text {degree }} \leq 214 \\
\frac{x_{\text {degreg }}-112.5}{-33.5} & 214 \leq x_{\text {degree }} \leq 247.5
\end{array}\right.
$$

$A_{\text {value and }} \mathrm{x}$ degree are the values for any cell in the mentioned map and aspect of each cell in degree, respectively.

Distance from transmission lines and road were other important parameters for site selection decision making. These parameters were valued as below (Asakereh, et al. 2014):

$$
D_{\text {value }}=\left\{\begin{array}{cc}
1 & x_{d} \leq 1000 \\
\frac{x_{d}-1000}{39000} & 1000 \leq x_{d} \leq 40000 \\
0 & \text { otherwise }
\end{array}\right.
$$

Where $\mathrm{D}_{\text {value }}$ and $\mathrm{x}_{\mathrm{d}}$ are the values of each cell in road community and grid approachability raster maps and distance of any x cell in meter, respectively.

Afterward, pairwise comparisons for defined criteria and intuition, and the relative intensity of importance of each evaluation factor were calculated. By using obtained data, which were attained from above relations, and applying GIS appropriate sites for solar farms were obtained.

Lozano et al (2015) evaluated the appropriate location for installation of solar thermoelectric power plants by employing AHP and TOPSPIS approaches were used in their research. In addition, GIS, was applied to 
select the best location. In the study, AHP was used to obtain the weights of the criteria and fuzzy TOPSIS method was applied in order to assess alternatives.

The main criteria which were considered in this study are shown in Figure 2. Experts were requested to affirm weights for each criterion. Based on the obtained weights and applying GIS, the best location for thermoelectric plants site was chosen. Vafaeipour et al (2014) also conducted a research to assess region priority for installation of solar projects in Iran by using a hybrid multi-criteria decision making. Their study utilized Stepwise Weight Assessment Ratio Analysis - weighted aggregated sum product assessment (SWARA-WASPAS) method. The structure for the problem which was designed by the authors is shown in Figure 3 .

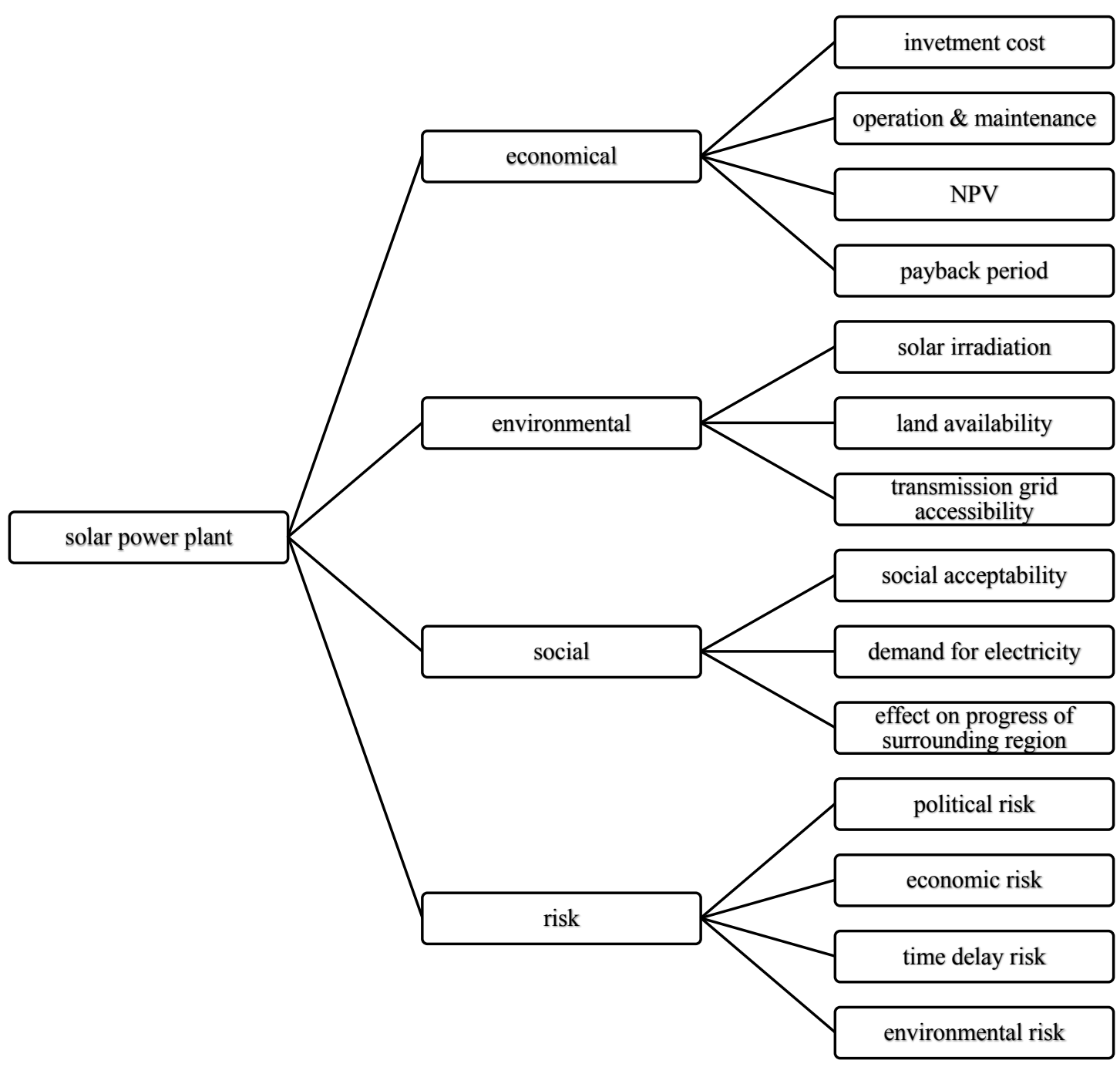

Fig. 3 Problem structure for solar site priority (Vafaeipour, et al. 2014)

By applying the mentioned method and using GIS, following results were obtained for Iran. In another study, Watson and Hudson (2015) investigated solar farm suitability by using GIS and multi-criteria evaluation. Method applied in their study was AHP and the case study was located in the UK. The important factors affecting decision making for the mentioned purpose are listed in Table 3. For obtaining pairwise comparisons, seven experts in renewable energy were asked to present pairwise comparison of the criteria. Based on obtained results and using GIS and applying AHP method, the selection priorities were represented for decision making on solar farm suitability. Uyan (2013) worked on selecting solar farms site in Konya/Turkey by using GIS and AHP method. In decision making process, criteria, environmental and economic factors, and their weights had to be defined by experts. Environmental factors considered in this study were distance from residential areas and land use while economic factors had three subcriteria including distance from roads, slope and distance from transmission lines.

Table 3.

Important criteria for decision making (Watson and Hudson 2015)

\begin{tabular}{ll}
\hline Technical & Solar radiation \\
\hline Visual & $\begin{array}{l}\text { Distance from historically } \\
\text { important areas }\end{array}$ \\
& $\begin{array}{l}\text { Distance from residential areas } \\
\text { Ecological }\end{array}$ \\
Economic & $\begin{array}{l}\text { Distance from wildlife designations } \\
\text { Distance from transport links }\end{array}$ \\
& \\
\hline
\end{tabular}




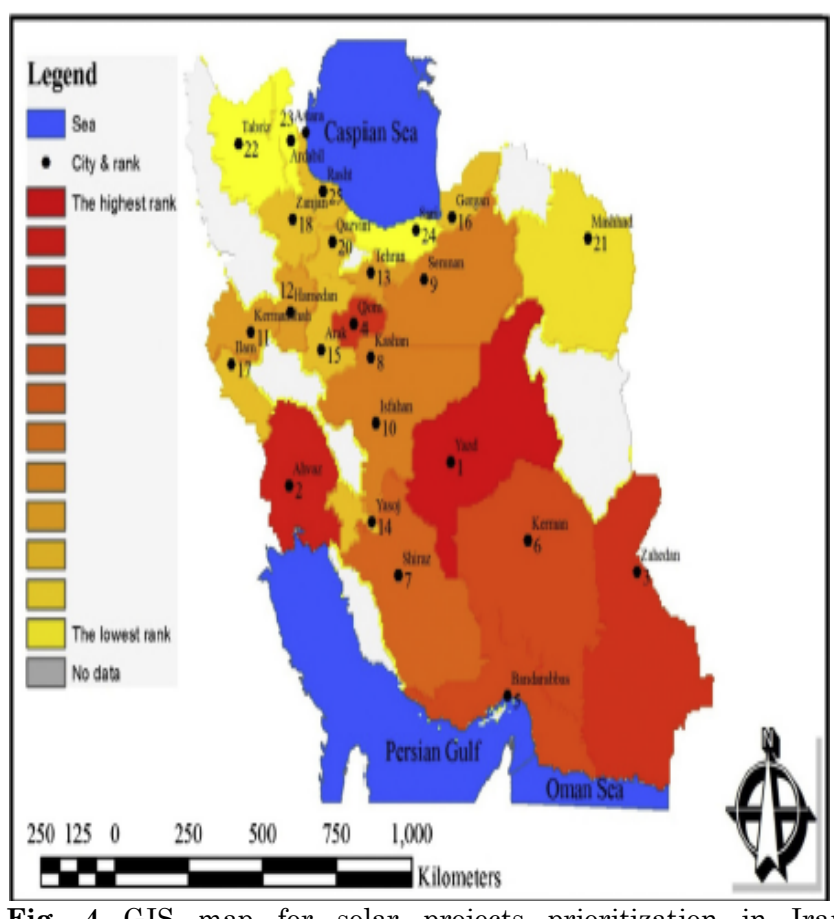

Fig. 4 GIS map for solar projects prioritization in Iran (Vafaeipour, et al. 2014)

Chen et al (2014) used a hybrid MCDM model for improving GIS-based solar farm site selection; they applied DEMATEL and DANP methods for their analysis. Their researches showed that $\mathrm{C} 1$ : agrological capacity, C2:slope, orientation, C3: required area for solar farm, C4: distance to roads, C5: distance to power grids, C6: distance to villages or rural locations, C7: distance to substations,C8: solar radiation and C9: mean temperature C10: average temperature are criteria which affect decision making for selecting solar farm. They numbered these criteria from 1 to 10 , respectively.

By using mentioned methods and weighted super matrix obtained from experts' suggestions, the best options were selected. Based on experts' suggestions, average temperature and solar radiation had highest effects and solar radiation received the most influences. Other studies for solar site selection used same criteria for evaluation; however, other criteria such as humidity have also been used in addition to mentioned criteria (Zoghi, et al. 2015).

Based on the literature reviews, it seems that the most important criteria for solar site selection can be defined as economic, environmental, visual, risk, technical, and geographical. Each criterion has a number of sub-criteria mentioned earlier.

\section{MCDM Approach in Selecting Solar Technology}

In MCDM approach can also be used to select the type of solar technology among all available types of solar technologies. In an extensive research, Nixon et al (2010) utilized MCDM approach to select the best solar thermal collection for electricity generation in north-west India. In their study, various technologies were compared based on three main criteria: technical, financial and environmental. To obtain an appropriate result, thermodynamic analysis and experts' suggestion were coupled with each other. The criteria and sub-criteria used in the study are shown in Figures $5 \& 6$.

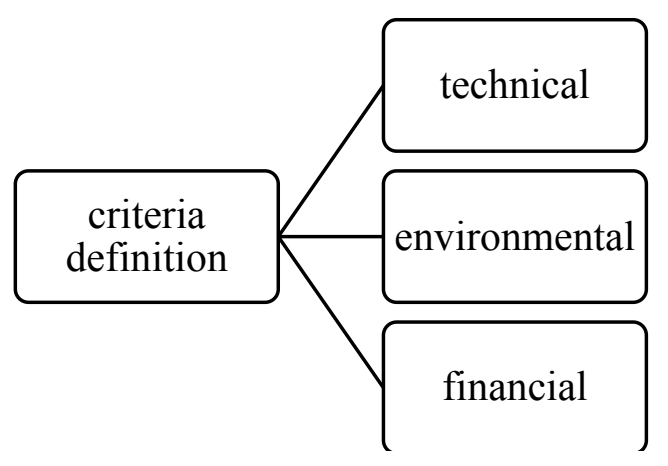

Fig. 5 Criteria definition (Nixon 2010)

In their study, ten experts were asked to score the criteria from 1 to 10. Experts' scores and the obtained pairwise comparisons led to their conclusion to select the best option. In another study, Cavallaro (2010) applied fuzzy TOPSIS method to assess thermal-energy storage in concentrated solar power systems. Based on the conducted review in the research, 10 criteria were selected to assess these systems. The criteria were divided into technical-economical, seven of ten considered criteria, and environmental criteria, three other criteria. The criteria in the research were defined as: investment cost, operating and maintenance cost, levelized electricity cost, levelized electricity cost reduction, thermal storage cost, electricity production, state of knowledge of innovative technology, environmental risk and safety, land use and freezing point (Cavallaro 2010). It was concluded that using molten salt is the best choice for heat transfer and thermal storage compared with other investigated options.

Table 4.

Criteria and sub criteria defined for recycling strategy in upstream of solar energy ( Shiue and Lin 2012)

\begin{tabular}{ll}
\hline Benefits & COA: Industry competitive advantages \\
& RPRM: Reduce production cost \\
& EFB: Increase economical and financial benefits \\
& COI: Enhance business image \\
ES: Save energy \\
ties & GP: The business that can fully comply with \\
& government rules has a winning edge over the \\
& others \\
& EC: Waste disposal has become a very important \\
& issue for business \\
QL: Special attention to the quality of life \\
TRC: Transportation cost \\
EBC: Equipment and building cost \\
LAC: Opportunity cost \\
SOR: Waste disposal cost, minimizing pollution \\
REPC: Education of costumer \\
CUR: Costumer risk \\
risks \\
FIR: Financial risk \\
IBPR: Internal business process risk \\
LIR: Uncertainty of legislative and political \\
conditions \\
LPR: Risk of newly developed type of logistics
\end{tabular}

Shiu et al (2012) employed analytic network process (ANP) to evaluate the optimal recycling strategy in upstream of solar energy industry. Based on their study, four main criteria could be listed and each criterion was divided into several sub-criteria shown in Table 4. 

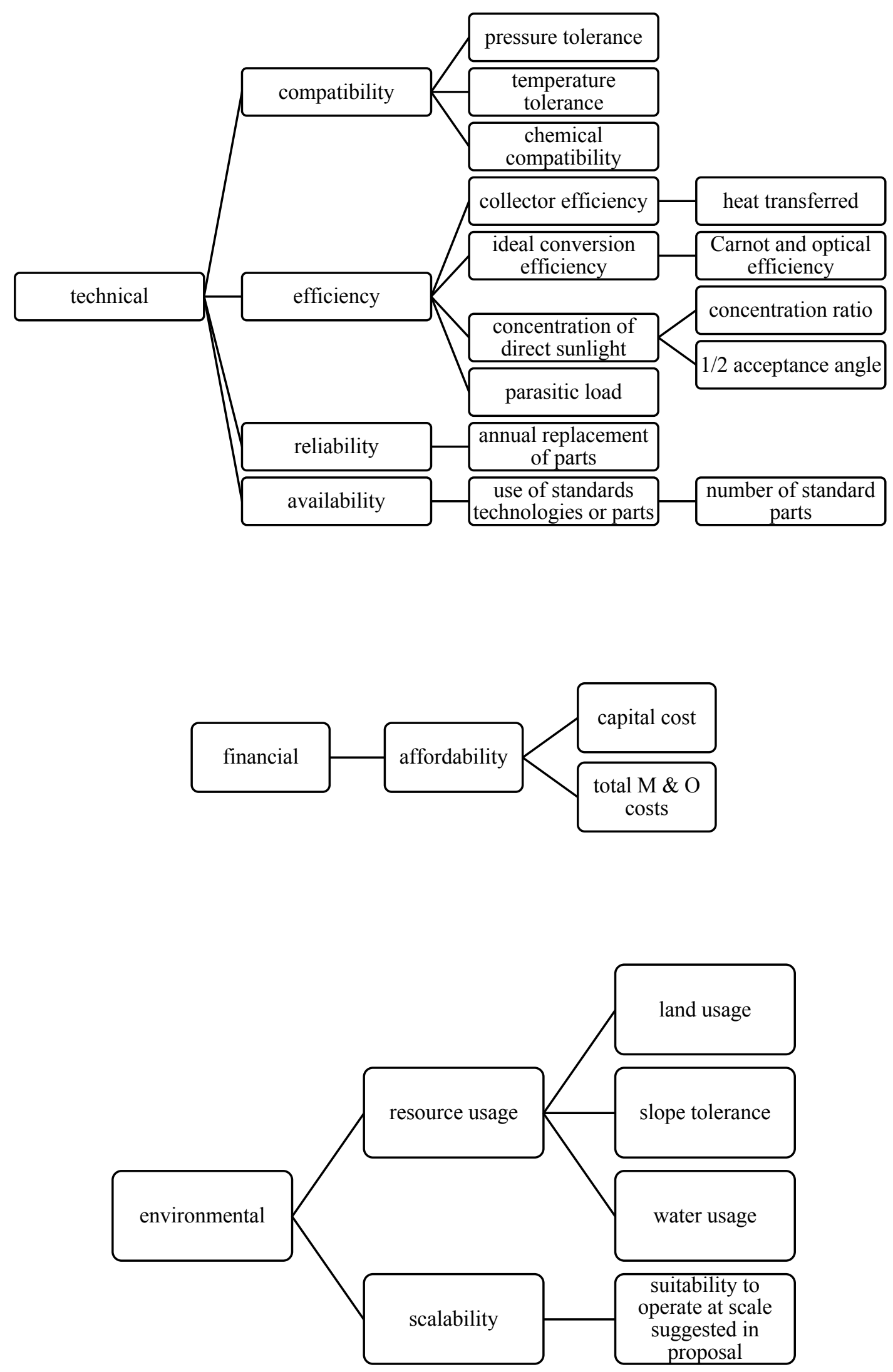

Fig. 6 Sub-criteria definition (Nixon 2010) 
By obtaining weights for each alternative, the best option was chosen based on weights of each criterion for each alternative and applying ANP method.

In a research conducted recently, Beltran et al (2014) used AHP/ANP MCDM approach for the selection of solar-thermal power plants. Their main criteria were risks, costs and opportunities. Risks included country risks, changes in energy policy, water supply for the plant, financing funding, effective solar radiation, natural gas supply in these plants, technology availability, intensity of natural disasters, easy access and proximity to power line. Costs comprised investment while opportunities covered experience and degree of knowledge, market diversification, future synergies and hampering competitions (Beltrán, et al. 2014).

Some studies have also been done to obtain the most appropriate technology among PV technologies which are available. For instance, Tang et al (2014) applied Delphi method and AHP for selection of key technologies by the available silicon photovoltaic industry. For the mentioned purpose, five main criteria were obtained based on their research which affect decision making for selecting key technologies. These criteria were: the expected influence on cost, the expected influence on efficiency, the expected influence on energy consumption, the gap between China (case study) and the rest of the world and the overall evaluation of the technology in addition to the former ones, since every expert might make an overall judgment and evaluation of a specific technology (Tang et al. 2014). In another study, manufacturing cost, efficiency in energy conversion, market share, emission of greenhouse gases, and energy returns times considered as the criteria for PV technology selection which were similar to previous study (García-Cascales 2012).

Zeyuan (2013) also conducted a research for selection of solar cell based on TOPSIS method. In this research, the criteria for selection of the technology were obtained as: generating cost, total generation (usually last for 35 years), net income, unit generation cost, investment payback period and return on investment (Zeyuan 2013). These were sub-criteria for two main criteria which were: economic criterion and generating criterion. Based on these sub criteria and weighted vector for each of them, depending on the case study, the best option was selected. In this research, equal weights were considered for all sub criteria. In another considerable research, Ahammed et al (2013) employed AHP model in rural areas of Bangladesh to select the most appropriate package of solar home system. Main criteria which were important for decision making in the research were: cost of the package (CP), meeting the demand of the basic household electricity need (HEN) and availability of the package(AP).

In addition to electricity generation, solar energy has also been used in other applications such as water heating. MCDM approach are used to evaluate the best technology in solar water heating systems. For example, Mohsen et al (1997) evaluated domestic solar water heating systems in Jordan by using AHP. Six main criteria, viz efficiency, reliability, availability of fuel, national economy, social benefits and safety, considered as the effective decision-making parameters. For decision making, scoring and relative weights of criteria against each other were obtained (Mohsen and Akash 1997). By using the data and weights of them for each system, the best option was selected.

In another study, Chandrasekhar et al (2013) applied MCDM approach for selecting suitable solar tracking systems. The criteria used in decision making process were reliability, accuracy, response, and repeatability of tracking system. Based on priority vectors and relative importance matrix, the best option for the case study was chosen. Andrsen (Andresen n.d.) also used a MCDM method for solar building design and based on done researches in the study, a myriad of parameters affected solar building design such as efficiency, flexibility, visual issues, energy conversion, life-cycle cost, security, size, operating costs, maintenance costs, thermal comfort (Andresen n.d.). They stated that the main criteria were small environmental loading, good architectural qualities, good economic performance, and good comfort. They too mentioned that active solar collectors, photovoltaic cladding, and increased window area were alternatives for building integrated solar energy system (Andresen n.d.). Based on these criteria and defined sub criteria, they concluded the best option could be selected for each case study. The best solar system depends on case study since relative weights and relation scoring for each case study which depend on many parameters such as region, energy policies, energy security and other effective parameters (Andresen n.d.).

Recently, Kaa et al (2014) used a fuzzy MCDM approach to select photovoltaic technology. They designed AHP decision hierarchy as shown in Figure 7.

By obtaining local weights for each criterion and applying FAHP and AHP, the best alternative was selected. In the research, weights of each criterion was obtained based on local priorities. In both used methods, technological superiority was the most important parameter for decision making and researchers allocated highest weight to it while pricing strategy and characteristics standard had lower importance for decision making, respectively (Kaa, et al. 2014). Nixon et al (2013) also utilized MCDM approach to design a novel solar thermal collector. Relative weights of criteria were obtained to select the best option. Figure 8 shows the relative weights of each criterion attained by the researchers.

Based on these criteria and attributed weights (experts' ideas) and considering other criteria obtained based on consumer priorities and by applying AHP method, the best option was achieved to be installed in the case study.

In another thorough study, Cavallaro (2009) used Preference Ranking Organization Method for Enrichment of Evaluation (PROMETHEE) method to assess concentrated solar thermal technologies. The criteria selected to compare alternatives based on them were: investment costs, operating and maintenance costs, levelized electricity costs, reliability of technology, environmental impacts, temperature output of the plant and solar capacity (Cavallaro 2009) factor which is defined as the ratio between solar operating hours per year and total hours in calendar year (8760). Based on mentioned criteria and by applying PROMETHEE approach, the best choice was selected. 


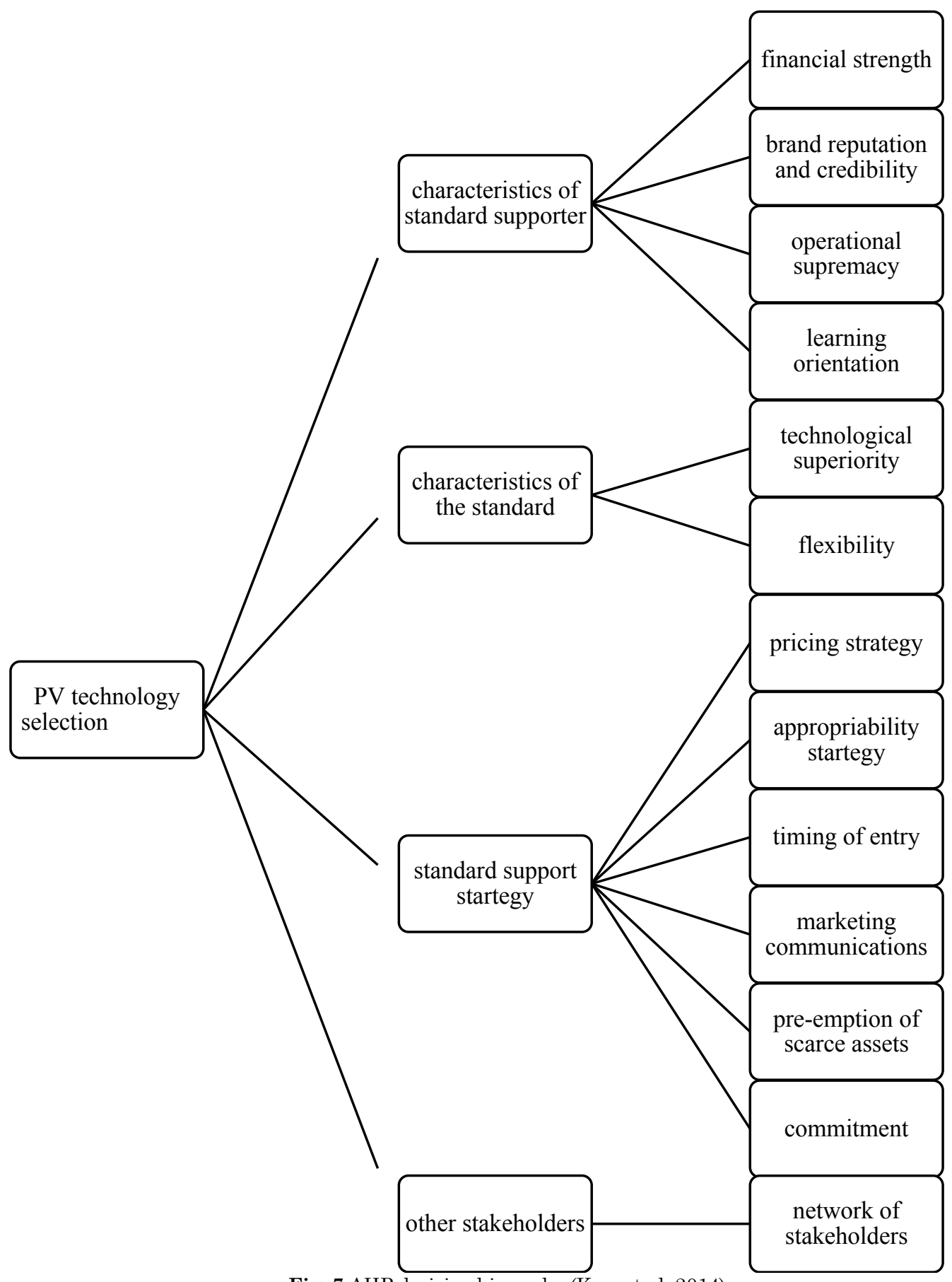

Fig. 7 AHP decision hierarchy (Kaa, et al. 2014)

\section{Conclusion}

In this study, employing MCDM approach in selecting site location for solar energy and selecting the best technology is investigated. Based on reviewed literature, it can be concluded that the main criteria in site selection are economy, environment, risk, geography, vision, ecology, society, and climate. Each of the mentioned criteria has a number of sub-criteria mentioned in the tables and figures of the study. For selecting solar technology, many criteria affect decision making such as technical aspects, economical aspects, feasibility, efficiency, land usage, flexibility, CO emission, reliability and accuracy.
It can be concluded that solar radiation is one of the most important factors since it is mentioned in all studies for site selection. Similar to the criteria for site selection, these criteria have also several sub-criteria. Each criterion and sub-criterion were mentioned and evaluated in this study. It is necessary to consider that for each country and location these criteria and their weights are different. Criteria, sub-criteria and their weights are significantly dependent on numerous parameters including energy policies, taxes, critical issues in each case study, and some other possible factors. However, it is highly recommended to get advice from experts to define criteria and their weights. It is more likely to achieve better decisions by using more suggestions. Moreover, different approaches of decision making can lead to different conclusion. 


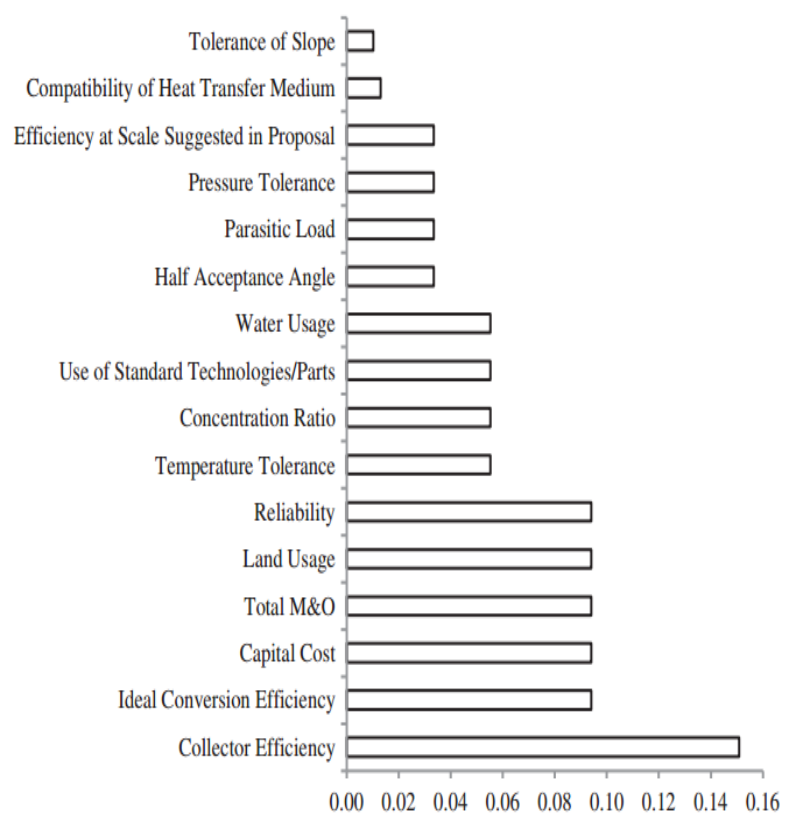

Fig. 8 Relative weightings for solar collectors criteria (Nixon 2013)

\section{References}

Ahammed, F. and Abdullahil, A. (2013). Selection of the most appropriate package of Solar Home System using Analytic Hierarchy Process model in rural areas of Bangladesh. Renewable Energy 55, 6-11.

Ahmad, S. and Razman, M.T. (2014). Selection of renewable energy sources for sustainable development of electricity generation system using analytic hierarchy process: A case of Malaysia. Renewable Energy 63, 458-466.

Amer, M. and Tugrul, U.D. (2011). Selection of renewable energy technologies for a developing county: A case of Pakistan. Energy for Sustainable Development 15, 420-435.

Andresen, I. (2000). A multi-criteria decision-making method for solar building design.

Arab, M., Soltanieh, M. and Shafii, M.B. (2012). Experimental investigation of extra-long pulsating heat pipe application in solar water heaters. Experimental Thermal and Fluid Science 42, 6-15.

Aragonés-Beltrán, P., Chaparro-González, F., Pastor-Ferrando, J.P. and Pla-Rubio,A. (2014). An AHP (Analytic Hierarchy Process)/ANP (Analytic Network Process)based multi-criteria decision approach for the selection of solar-thermal power plant investment projects. Energy $66,222-238$

Asakereh, A., Omid, M., Alimardani, R and Sarmadian, F. (2014). Developing a GIS-based Fuzzy AHP Model for Selecting Solar Energy Sites in Shodirwan Region in Iran. International Journal of Advanced Science and Technology 68, 37-48.

Baniasad A, I., Sadegh, M.O and Ameri, M. (2015). Energy management and economics of a trigeneration system Considering the effect of solar PV, solar collector and fuel price. Energy for Sustainable Development 26: 43-55.

Cavallaro, F. (2009). Multi-criteria decision aid to assess concentrated solar thermal technologies. Renewable Energy 34 (7), 1678-1685.

Cavallaro, F. (2010). Fuzzy TOPSIS approach for assessing thermal-energy storage in concentrated solar power (CSP) systems. Applied Energy 87 (2), 496-503.

Chandrasekhar, V, Marthuvanan, M., Ramkumar,M.M., Shriram,R. Manickavasagam,V.M. and Ramnath, B.V.
(2013). MCDM approach for selecting suitable solar tracking system. 7th International Conference on Intelligent Systems and Control (ISCO).

Chatzimouratidis, A.I. and Petros A. Pilavachi, P.A. (2008). Multicriteria evaluation of power plants impact on the living standard using the analytic hierarchy process. Energy Policy 36 (3), 1074-1089.

Chatzimouratidis, A. I., and Pilavachi P.A. (2009). Technological, economic and sustainability evaluation of power plants using the Analytic Hierarchy Process. Energy Policy 37 (3), 778-787.

Chen, C-R, Huang,C.C and Tsuei, H.J (2014). A Hybrid MCDM Model for Improving GIS-Based Solar Farms Site Selection. International Journal of Photoenergy.

Dellosa, JT. (2016). Potential Effect and Analysis of High Residential Solar Photovoltaic (PV) Systems Penetration to an Electric Distribution Utility (DU). Int. Journal of Renewable Energy Development 179-185.

García-Cascales, M., Socorro, Lamata, M.T. and Sánchez-Lozano, M.J. (2012). Evaluation of photovoltaic cells in a multicriteria decision-making process. Annals of Operations Research 199 (1), 373-391.

Gupta, N. (2011). Material selection for thin-film solar cells using multiple attribute decision making approach. Materials \& Design 32 (3), 1667-1671.

Hoque, N., Roy, A., Beg, M.R.A. and Das.B.K. (2016). TechnoEconomic Evaluation of Solar Irrigation Plants Installed in Bangladesh. Int. Journal of Renewable Energy Development 73-78.

Jahangiri, M S., Gholami, D., Ghiasi, M., Shafii, MB and Shiee.Z. (2014). Experimental investigation of the effect of using thermosyphon heat pipes and vacuum glass on the performance of solar sti. Energy 75, 501-507.

Kaa, G, Rezaei, J., Kamp, L and de Winter, A. (2014.) Photovoltaic technology selection: A fuzzy MCDM approach. Renewable and Sustainable Energy Reviews $32,662-670$.

Kabak, M and Dağdeviren, M (2014). Prioritization of renewable energy sources for Turkey by using a hybrid MCDM methodology. Energy Conversion and Management 79, $25-33$.

Kahraman, C., I Kaya,I and Cebi.S. (2009). A comparative analysis for multiattribute selection among renewable energy alternatives using fuzzy axiomatic design and fuzzy analytic hierarchy process. Energy 34 (10), 16031616.

Kengpol, A., Rontlaong, P. and Tuominen.M. (2013). A Decision Support System for Selection of Solar Power Plant Locations by Applying Fuzzy AHP and TOPSIS: An Empirical Study. Jouranl of Software Engineering and Application 6 (9).

Kumar, R., and Singal. S.K. (2015). Selection of Best Operating Site of SHP Plant based on Performance. Procedia Social and Behavioral Sciences 189,110-116.

Luthra, S., Govindan, K., Ravinder K. K, and Mangla, S.K. (2016). Evaluating the enablers in solar power developments in the current scenario using fuzzy DEMATEL: An Indian perspective. Renewable and Sustainable Energy Reviews 63,379-397.

Miguel Sánchez-Lozano, J., Socorro García-Cascales, M. and Teresa Lamata. M. (2013). Decision Criteria for Optimal Location of Solar Plants: Photovoltaic and Thermoelectric. Assessment and Simulation Tools for Sustainable Energy Systems 129,79-91.

Mohsen, Mousa S., and Bilal A. Akash. 1997. "Evaluation of domestic solar water heating system in Jordan using analytic hierarchy process." Energy Conversion and Management 38 (18): 1815-1822.

Naick, B.K., Chatterjee,T.K. and Chatterjee, K (2017). Performance Analysis of Maximum Power Point Tracking Algorithms Under Varying Irradiation. Int. Journal of Renewable Energy Development 65-74.

Narei, H., Ghasempour, R. and Noorollahi.Y. (2016). The effect of employing nanofluid on reducing the bore length of a 
vertical ground-source heat pump. Energy Conversion and Management 123, 581-591.

Narei, H., Ghasempour,R. and Noorollahi, Y (2016). The effect of employing nanofluid on reducing the bore length of a vertical ground-source heat pump. Energy Conversion and Management 123, 581-591.

Nigim, K., Munier, N.and Green. J. (2004). Pre-feasibility MCDM tools to aid communities in prioritizing local viable renewable energy sources. Renewable Energy 29 (11): $1775-1791$.

Nixon, J.D., Dey, P.K. and Davies. P.A. (2010). Which is the best solar thermal collection technology for electricity generation in north-west India? Evaluation of options using the analytical hierarchy process. Energy 35 (12), 5230-5240.

Nixon, J.D., Dey, P.K. and Davies. P.A. (2013). Design of a novel solar thermal collector using a multi-criteria decisionmaking methodology. Journal of Cleaner Production 59: $150-159$.

Noorollahi, Y., Ghasempour, R. and Jalilinasrabady, S. (2015). A GIS Based Integration Method for Geothermal Resources Exploration and Site Selection. Energy Exploration \& Exploitation 33 (2): 243-257.

Olimat, A.N. (2017). Study of Fabricated Solar Dryer of Tomato Slices Under Jordan Climate Condition. Int. Journal of Renewable Energy Development 93-101.

Pohekar, S.D., and Ramachandran, M. (2004). Application of multi-criteria decision making to sustainable energy planning-A review. Renewable and Sustainable Energy Reviews 8 (4), 365-381.

Sánchez-Lozano, J.M., García-Cascales, M.S. and Lamata M.T. (2015). Evaluation of suitable locations for the installation of solar thermoelectric power plant. Computers \& Industrial Engineering 87, 343-355.

Şengül, Ü., Miraç,E., Shiraz, S.E., Gezder, V. and Şengül, A.B. (2015). Fuzzy TOPSIS method for ranking renewable energy supply systems in Turkey. Renewable Energy 75, $617-625$.

Shiue, Y.-C. and Lin. C-Y. (2012). Applying analytic network process to evaluate the optimal recycling strategy in upstream of solar energy industry. Energy and Buildings 54, 266-277.

Singh, A., Vats, G and Khanduja. D. (2016). Exploring tapping potential of solar energy: Prioritization of Indian states. Renewable and Sustainable Energy Reviews 58, 397-406.

Tang, Y., Sun, H., Yao, Q. and Wang. Y. (2014). The selection of key technologies by the silicon photovoltaic industry based on the Delphi method and AHP (analytic hierarchy process): Case study of China. Energy 75, 474-482.

Tarwidi, D., Murdiansyah, D.T. and Ginanjar.N (2016). Performance Evaluation of Various Phase Change Materials for Thermal Energy Storage of A Solar Cooker via Numerical Simulation. Int. Journal of Renewable Energy Development 199-210.

Toghi E., Amin, R. G., Fatemeh, R. and Fatollah, P. (2015). Evaluation of nanoparticle shape effect on a nanofluid based flat-plate solar collector efficiency. Energy, Exploration \& Exploitation 33 (5).

Uyan, M. (2013). GIS-based solar farms site selection using analytic hierarchy process (AHP) in Karapinar region, Konya/Turkey. Renewable and Sustainable Energy Reviews 28, 11-17.

Vafaeipour, M., Sarfaraz, H. Z., Varzandeh, M.H.M, Derakhti, A. and Eshkalag,M.K. (2014). Assessment of regions priority for implementation of solar projects in Iran: New application of a hybrid multi-criteria decision-making approach. Energy Conversion and Management 86, 653663.

Watson, J. and Malcolm D. H. (2015). Regional Scale wind farm and solar farm suitability assessment using GIS-assisted multi-criteria evaluation. Landscape and Urban Planning 138, 20-31.

Zeyuan, Y. (2013). Selection of Solar Cell based on TOPSIS Method. International Conference on Advanced
Information Engineering and Education Science (ICAIEES 2013).

Zoghi, M., Amir, H.E., Mahdis, S., Amiri,,M.J and Sepideh, K (2015). Optimization solar site selection by fuzzy logic model and weighted linear combination method in arid and semi-arid region: A case study Isfahan-IRAN. Renewable and Sustainable Energy Reviews. 